\title{
Fall or Rise? Mapping the Development of Traditional and Digital Newspapers
}

\author{
Muhammad Ramzan Pahore ${ }^{1 *}$, Sumera Memon ${ }^{2}$, and Qaiser Khan ${ }^{3}$
}

\begin{abstract}
Daily newspapers in the world are shrinking in many dimensions. All big or small newspapers are getting smaller in size, business and news circulation. The speed at which newspapers are shutting down is not much different from the early 20th century. Thus, most newspapers are shifting from conventional setting to onlinel digital newspapers only. Since the last two decades, the business of newspaper has declined as many newspapers have migrated business and appearance online to retain print readers via online only consumers and attract new ones who are just netters in the world. This change has been noticed in all countries. Pakistan is also one among those countries in which new technology is being adopted in the field of media. Due to information communication technologies, most of the Pakistani print, electronic media organization has switched to online to keep pace with the developed world. Hence, most of the conventional/traditional newspapers become digital newspapers along with print publications. Therefore, this paper discusses the history and development of online newspapers. Digital media has the power to attract many young news consumers because of its convenience, ease of excess, update 24/7 and availability at any time. These features are the prime source of newspaper decline and a major source of digital media growth.
\end{abstract}

Keywords: Newspaper Decline; Rise of Online Newspaper; Pakistan; Digital Media.

\section{Introduction}

In the arena of mass media, the Internet has been described as one of the most In the arena of mass media, the Internet has been described as one of the most significant and revolutionary developments in the 21 st century. This has provided new paths for online newspaper development. The Newspaper Association of America (NAA) confirms that the first electronic newspaper was introduced in 1993. In this connection, Charney and Green (2002) say radio took 38 years to attain 50 million listeners in America; television had to wait 13 years to get 50 million viewers while it took cable television 10 years to knock this target number of audience. However, the Internet-based media took just five years to achieve even more traffic. The surge of online media

\footnotetext{
${ }^{1}$ Department of Media \& Communication Studies, University of Sindh, Jamshoro.

${ }^{2}$ Department of Media \& Communication Studies, Sindh Madressatul Islam Karachi, Sindh Pakistan.

${ }^{3}$ Department of Media Studies, Bahria University Islamabad, Pakistan.

*)Corresponding Author.

Email: mramzan@usindh.edu.pk
} 
has continued to increase as 934 million consumed online media in 2004, similarly, the figure was projected to 1.07 billion in 2005 and 1.21 billion in 2006, and the number continued to grow (Nguyen, 2008). Hence, with the popularity of the Internet, the complete news system and business models of traditional newspapers have changed, thereby demanding new approaches and values to news production and distribution (Organization for Economic Cooperation and Development, 2009).

Shortly after Tim Berners Lee invented the World Wide Web in 1990 and University of Illinois students' consequent opening of Mosaic (the first web browser) in 1993, the traditional media hastily established an online presence to attract consumers and retain them to generate revenue, to remain relevant and expand their outreach and consumption (Nguyen, 2007). Still, after this development, the proliferation of online newspapers was slow until 1994, when around 20 online newspapers came into existence in the online market (Hermansson, 2013). These included the New York Times, Halifax Daily News, Wired Magazine, London Daily Telegraph and Financial Times.

In 1995, newspaper companies established their group, consisting of nine companies, including the New York Times and Washington Post (Shedden, 2010). Additionally, in 1996, Mercury Centre became the first daily completely online newspaper with a focus on developing a newspaper website on the World Wide Web. Also, Boczkowsksi (2005) reported that in 1995, the majority of the American newspapers went through an experimental period of adopting web publication. This process was characterized by what Boczkowski (2005) calls "hedging" that is, the growth of practices to deal with the uncertainty of websites' development as a news platform (p. 51). Since then, the Internet has gained increasing importance as the source of news in the current process of news production and circulation. This importance is evident in not only the developed nations but also the developing and underdeveloped ones.

For instance, the US alone witnessed more than 1,500 daily newspapers supply of online editions, and reports have shown that $76 \%$ of Internet users consume online newspapers (Journalism.org, 2007). This is why the Internet has been considered as one of the key strategies to retain and regain consumers (Yoo, 2011). Notably, due to Internet penetration as a powerful tool of communication and information dissemination, Google introduced the Google News service in April 2002 and the same year for the first time; users were asked to pay for online content (Shedden, 2010).

Later in 2003, news organizations started asking their consumers to contribute news. For instance, the BBC asked for content on the Iraq conflict after the 9/11 terrorist attack in Washington. This shows how committed and involved consumers of online newspapers are and the level they are willing to go in consuming and even contributing to online newspapers (Madden, 2010).

The growth rate of online newspapers witnessed alike in the developed, developing and underdeveloped world. For instance, from virtually zero in 1993, there were 3,112 online newspapers, 3,900 online magazines, 
2,108 radio sites and 1,823 TV sites recorded from the developing countries as of 1998 (Nguyen, 2007). Also, the World Association of Newspapers reported in 2001 that 5400 newspapers worldwide had an online/web edition, and thus figures are continuously increasing. For the 1999-2000 period, for instance, there was a remarkable numerical expansion from 1,149 to 1,207 in the US, 29 to 85 in Spain, 122 to 172 in Australia and 179 to 232 in Germany. By 2002, Editor and Publisher reported that traditional news organizations set up a total of 13,536 news websites (Nguyen, Ferrier, Western, \& McKay, 2005). Meanwhile by the middle of 2000, "virtually all mainstream newspapers and broadcasters" in North America had an Internet site, with "an increasing number of community newspapers and local broadcasters joining the trend" (Eid \& Buchanan, 2005). According to the World Association of Newspapers (2006), the worldwide number of newspapers with websites increased by $20 \%$ in 2005.

In view of this, this paper is set out to trace and narrate the history and development of online newspapers in Pakistan.

\section{Rise of Online news media in Asia}

Digital development trends are seen in Asian countries such as China, Malaysia, Pakistan and India, where most of the newspaper organizations brought their publications online due to the decrease in print newspaper readership and circulation. In the case of Malaysia, Utusan Online was the first media house to have an electronic newspaper and the development attracted quite a good number of newspaper consumers (Ariffin, \& Jaafar, 2009). Furthermore, Ariffin and Jaffar (2009) asserted that the Utusan Online website recorded an average of 15-20 million hits, with over four million pages viewed every month in 2008. Similarly, Pakistan experienced a decline in the readership of conventional newspapers while online readership increased significantly (Shokat, 2011; Memon \& Pahore, 2014; 2015; Pakistan Bureau of Statistics, 2012). Following this trend, it is fair to conclude that online news platforms are overcoming the traditional print newspapers as a primary source of relevant and timely information among a lot of people. Thus, as the online newspaper platforms increase in readership and relevance, it is therefore important to study the consumption of online newspapers. Online newspaper consumption is especially important with regards to the social and psychological factors that are responsible for explaining the consumption behaviour of news consumers.

With the decline of traditional newspapers in the 21st century, Pakistani newspaper circulation has declined and the number of newspapers has also reduced. Although newspaper circulation figures have dropped drastically in recent years, print media remains the main source of news for millions. Updated figures from the marketing research organization Gallup Pakistan say 60 per cent of urban populations and 36 per cent of rural populations read newspapers (Pakistan Bureau Statistics, 2011). The Pakistan Bureau Statistics (hereafter PBS) stated that a total of 749 newspapers and 
periodicals were published in 2011, out of which 594 were in the Urdu language, 67 in English, 17 in Sindhi and the rest published in regional languages (Pakistan Bureau of Statics, 2012). Similarly, Ali (2011) stated that the newspapers are published in 11 languages but the majority of them are published in three languages; Urdu, Sindhi, and English.

Total Numbers of Print Publications by Language, 2002-2011

\begin{tabular}{|l|l|l|l|l|l|l|l|l|l|l|}
\hline Language & $\mathbf{2 0 0 2}$ & $\mathbf{2 0 0 3}$ & $\mathbf{2 0 0 4}$ & $\mathbf{2 0 0 5}$ & $\mathbf{2 0 0 6}$ & $\mathbf{2 0 0 7}$ & $\mathbf{2 0 0 8}$ & $\mathbf{2 0 0 9}$ & $\mathbf{2 0 1 0}$ & $\mathbf{2 0 1 1}$ \\
\hline Arabic & 4 & 4 & 4 & 5 & 3 & 5 & n/a & n/a & 2 & n/a \\
\hline Balochi & 8 & 11 & 13 & 17 & 8 & 8 & 8 & 12 & 13 & 12 \\
\hline Bi/trilingual & 3 & 14 & n/a & n/a & 1 & n/a & n/a & n/a & n/a & n/a \\
\hline Brahvi & 4 & 4 & 2 & 2 & 3 & 3 & 3 & 4 & 4 & 4 \\
\hline English & 153 & 204 & 223 & 290 & 133 & 252 & 100 & 56 & 84 & 67 \\
\hline Gujrati & 8 & 13 & 13 & 15 & 3 & 1 & n/a & n/a & n/a & n/a \\
\hline Punjabi & 1 & 1 & 2 & 8 & 5 & 7 & 6 & n/a & 2 & 7 \\
\hline Pushto & 8 & 9 & 14 & 35 & 34 & 33 & 14 & 18 & 17 & 17 \\
\hline Saraiki & 1 & 4 & 4 & 5 & 1 & 1 & 1 & n/a & 5 & n/a \\
\hline Sindhi & 33 & 53 & 58 & 80 & 35 & 12 & 22 & 16 & 26 & 17 \\
\hline Urdu & 497 & 628 & 895 & 1,533 & 1,236 & 1,490 & 1,042 & 600 & 761 & 594 \\
\hline Others & n/a & n/a & 51 & 7 & 2 & 8 & 3 & n/a & 38 & 31 \\
\hline Total & 720 & 945 & 1,279 & 1,997 & 1,464 & 1,820 & 1,199 & 706 & 952 & 749 \\
\hline
\end{tabular}

Source: Recchiardi (2012)

More recent reports have contradicted earlier figures. According to Recchiardi (2012), the number of daily newspapers is 252, with 139 weeklies and 279 monthlies. Furthermore, the bureau reported a combined daily sale of 6.1 million copies for all newspapers. The following Figure 1.1 represents the readership shares of big newspapers in Pakistan. It shows that Jang, among highly circulated/ consumed newspapers in Pakistan, is the largest in terms of consumption.

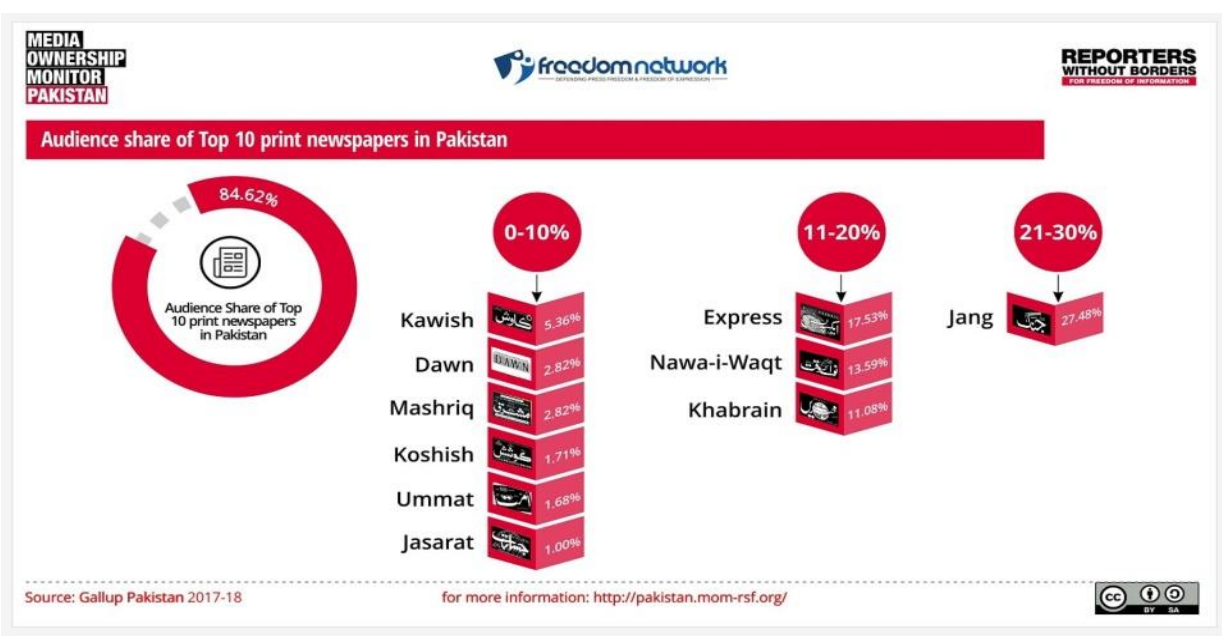

Figure 1.1. Newspaper Audience share in Pakistan (Gallup Pakistan, 2017-18) 


\section{Rise of Online Media}

Online media is a recent phenomenon that emerged after the Internet penetration in Pakistan. The first Pakistani online newspaper is Dawn in English, which appeared first on the Internet in 1996 (Shokat, 2011). Dawn's news website (www.dawn.com) soon became successful, with over 10 million page views per month. Dawn has as well remained the most popular online newspaper in Pakistan (Yusuf et al., 2013). Moreover, in the same year, another English newspaper - The News - also started to appear on the Internet (The News, 2012). Later in 1998, Jang, which is the leading Urdu newspaper, developed its website on the Internet (Jang, 2007) and has remained one of the biggest newspapers on the web, with 1.2 million online users. Indeed, it is reported that Jang newspaper page views are more than 30 million per month.

The actual phenomenon of digitalization and online media proliferation increased as a result of a long time struggle for freedom of press and news reports. Pre-online media in Pakistan was an era of excessive control from the government, especially during the administration of President Musharaf, who clamped down on press freedom and as a result, banned so many traditional media organizations (Memon \& Shaikh, 2019). Such hostility pushed many journalists towards writing and sharing their opinions online. As such, Pakistani journalists found solace in sharing their opinions and reports online, therefore reinforcing the emergence of online media in Pakistan (Yusuf et al., 2013).

Consequently, all daily newspapers in English, Urdu and Sindhi began to incorporate their services online (Shokat, 2011) for easy and fast accessibility of information. In support of this claim, authors (Yusuf et al., 2013; Pahore, Memon, \& Shahzad, 2018) pointed out that the circulation of traditional newspapers has dropped in recent years. More so, the advent of online newspaper production has also increased the numbers of newspaper readership (Gallup-Pakistan, 2018), especially because online newspapers are quickly and easily accessible anywhere and anytime.

Consistently, Haque (2014), editor of the online Dawn newspaper (the leading English newspaper), reported that all around the world, print media is either by default shifting to websites as digital trends are adopted by media organizations, or they are in competition with other publications to attract people, so newspaper organizations fully avail themselves of the web opportunity. In consonance with newspapers, TV has also moved online to offer service video clips and live stream on the Internet.

Additionally, Haque (2014), complimenting online newspapers and online news sources, comments that after the onslaught of the popularity of online newspapers and news available on the web, editors, reporters and even news stories get feedback in the form of comments, likes and dislikes. Such inventions are attracting print organizations to become online newspaper organizations. 
Furthermore, to complement online newspapers, Memon (2011) explained that due to the growing number of Internet users in the country, many newspapers have started Internet editions (online newspapers) for local as well as expatriate Pakistanis. Such newspapers include English newspapers like Daily Dawn, The Nation, The News International, Daily Times and some Islamabad-based newspapers such as Din and Daily Hot News. Urdu newspapers like Daily Jang and leading newspapers in terms of circulation; Daily Nawa-e-Waqt, Jasarat Friday Times (weekly), The Frontier Post, Hi Pakistan, Information Times, Pakistan Link, Pakistan News Service and Pakistan Press International (PPI) also all have online newspaper websites (Memon \& Pahore, 2015).

\section{Internet and News Consumption}

Advancement in Information and Communication Technologies (ICTs) have accompanied in more robust variation in newspaper publishing into online versions, thus providing news organizations with the view for better connectivity and interactivity with newspaper readers (Okonofua, 2012). Since the last decade, Pakistan has experienced rapid development and growth in Information and Communication Technologies (ICTs), which has resultantly had an immense impact on Pakistani media and society. In this connection, it is reported by the Pakistan Telecommunication Authority (hereafter PTA) that Internet access has been available in the country by the mid-1990s (PTA, 2016). Later, with the help of Pakistan Telecommunication Authority Limited (PTCL), Internet service was offered to the masses through local call networks in 1995. Furthermore, Memon (2011) writes in his doctoral thesis that not only did PTCL offer Internet services, but some other companies also provided Internet services in Karachi and other parts of the country. Such companies include Digicom and Fascom (in 1996), which subsequently became a source of news and entertainment.

Broadband Internet and mobile cellular services are very important in connecting lives, providing platforms to media organizations for the dissemination of news and entertainment content and engendering freedom of speech in the 21st century. New emerging trends creating vibrant environments for online experience for newspaper consumers also help newspaper organizations to provide content to consumers (PTA, 2016).

Besides, according to the CIA World Fact Book (2010) and Memon (2011), Pakistan witnessed a total of 18.5 million Internet users in 2008, making it one of the top 20 countries in Internet use in the world. In contrast to these figures, the CIA Fact Book (2015) reports that Pakistan stands at the 27 th position in Internet use in 2014, and assert that 21.3 million people actively used the Internet at that time. Besides, 135.8 million people used mobile then. Surprisingly, Pakistan stood in the 11th position in the world for the number of mobile users in 2014. This indicates that people are moving towards online sources for news, information, entertainment and communication. Furthermore, it is affirmed that a significant increase has been 
reported since 2005, and more than 50 Internet service providers have been operating since then, hence, more than 29 million Internet users are using the Internet actively, which amounts to 16 per cent of the total population (Internet Service Providers Association of Pakistan, 2012; Yusuf et al., 2013). Also, the PTA successfully auctioned for the Next Generation of Mobile Services (3G/4G) (PTA, 2016). Due to this, mobile penetration has increased and reached 76.6 per cent with 139.9 million subscribers at the end of June 2014 (PTA, 2016). Within a short period of two months, Cellular Mobile Operators (CMOs) acquired 11.04 million new Internet subscribers through mobile, with 9.1 per cent growth during the financial year 2014, which covers 92 per cent of the land area of Pakistan. During the same period, Broadband also recorded a 39 per cent increase in the subscription to reach 3.79 million Internet users.

Internet and Information Communication Technologies provide a platform for media organizations to keep pace with the changing world and gain more audiences. Some media organizations feel new media technology is a threat that may wipe out their established reputations and markets (Haque, 2014). Therefore, Haque stresses that all media organizations moved to the Internet and adopted it as their primary platform for news dissemination to retain regular consumers and attract new consumers who are tech-savvy. In this regard, Express Tribune (a reputable English newspaper) and Express Urdu newspaper conducted a survey in Pakistan on the use of the Internet and found that majority of the respondents were young and below 25 years of age. The survey concluded that more than 20 million Pakistanis are online and the number of Internet users will rapidly increase over time. Furthermore, it reported that the majority (94 per cent) of Internet users are from urban areas, have high-speed Internet access and frequently consume news information and entertainment media (Popalzai \& Haque, 2013).

Similarly, Rajer, Salim and Hassan (2010) stated that the Internet is a serious threat to traditional news media and conventional newspapers. Thus, newspaper readership is on the decline. Furthermore, Pahore, memon, and Shahzad (2018) confirm that due to Internet availability, all newspapers, TV stations and radio stations have shifted to the Internet, while newspapers now have both online and print publications. Resultantly, all online newspapers are gaining popularity among news consumers in Pakistan. The availability of online newspapers on the Internet has given support to newspapers in term of readership. Furthermore, due to proliferation and online availability, consumers have changed their choice of format for getting news and information from newspaper websites. Furthermore, Rajer et al.., (2010) opine that total readership will increase if we combine print and online readership, compared to what print media alone claims. In contrast to this, the Managing Director of the Jang group of publications said that newspaper readership has continued to increase despite the low number of newspapers in Pakistan (Managing Director of Jang). 
Online newspapers are the preferred source for news and information, as reported by Rajer et al. (2010), because they are free and available on the Internet for consumers without any subscription fee. All content is free to access for readers who want to consume online newspapers at any time to satisfy information, entertainment, social, personal and escapism needs. Likewise, Memon and Pahore (2015) surveyed the Internet and online newspaper access behaviour of academicians in Pakistan. The study concluded that academicians prefer to consume online newspapers and they prefer to access more than two online newspapers to gratify their needs. Furthermore, they reported that young people prefer to consume English newspapers compared to the old, and while academicians have different preferences, all consume online newspapers regularly.

On the other hand, Memon (2014) surveyed traditional media use among the journalists of Sindh, Pakistan and found that journalists have different preferences in media consumption. While Sindh journalists prefer to consume more of print media, Urdu journalists prefer the TV, and as for age cohorts, younger journalists prefer to consume newspapers in both online and traditional print formats to gain information and updates. Furthermore, results confirm that majority prefer to consume online newspapers.

In addition, Rozee Pak Poll research organization surveyed with one question; "Do you prefer reading newspapers online?", and this was posted on various groups and pages on social media. Findings confirm that more than 50 per cent of the Internet user population prefers to read online newspapers daily for information, entertainment, social, personal and escapism needs. Also, 30 per cent read such sometimes, while 11 per cent often go to consume newspapers online (Rozee Pak Poll, 2013). Furthermore, Yusuf et al. (2013) assert that due to advancement in technology and availability to the masses, increased growth of online news consumption is being recorded in Pakistan. Furthermore, Yusuf reported that satellite news consumption has dropped from 6.5 per cent in 2005 to less than 4 per cent in 2010 due to TV channel streaming on the Internet.

\section{News Consumption on Social Media}

Moreover, audiences consume news from established pages of news organisations on social networking sites like Facebook and Twitter and known and popular newspapers maintain and update their pages on Facebook and Twitter regularly. Consumers follow Twitter pages of newspapers and like the Facebook pages of online newspapers to get up to date news. Follower numbers of Dawn, Jang, Kawish, The News, Daily Times and Express Tribute are continuously increasing, which indicates that people are moving towards online sources to satisfy their information, entertainment, escapism and social integrative needs.

Despite the growth of the independent blogosphere, established media group blog pages are very popular and dominant in the Pakistani blogosphere. Some newspapers like Urdu language Daily Jang and English dailies Express 
Tribute, Dawn and The News are top among blogs in terms of traffic in Pakistan (see Table 2.2). Most English newspapers maintain many bloggers who contribute and publish their posts on established news websites because online newspapers offer greater exposure and access to the masses while helping to attract more consumers.

Table 2.2: Top 10 Local Websites

\begin{tabular}{|l|c|c|c|c|}
\hline No & Local Website & $\begin{array}{c}\text { Rank Overall } \\
\text { in Pakistan }\end{array}$ & Type of Site & $\begin{array}{c}\text { Domain } \\
\text { Registry Date }\end{array}$ \\
\hline $\mathbf{1}$ & Olx.com.pk & 11 & Classifieds & 2007 \\
\hline $\mathbf{2}$ & Jang.com.pk & 13 & News & 1998 \\
\hline $\mathbf{3}$ & Geo.tv & 17 & News & 2002 \\
\hline $\mathbf{4}$ & Express.com.pk & 19 & News & 2001 \\
\hline $\mathbf{5}$ & Hamariweb.com & 26 & Diversified portal & 2006 \\
\hline $\mathbf{6}$ & Rozee.pk & 36 & Jobs portal & 2006 \\
\hline $\mathbf{7}$ & Tribune.com.pk & 41 & News & 2010 \\
\hline $\mathbf{8}$ & Zemtv.com & 48 & News & n/a \\
\hline $\mathbf{9}$ & Thenews.com.pk & 51 & News & 1999 \\
\hline $\mathbf{1 0}$ & Dawn.com & 55 & News & 1997 \\
\hline
\end{tabular}

Source: Yusuf (2013)

\section{Conclusion}

Since the Internet is diffused all over the world. News media has tuned the pace with news technology in their organizations. Thus, it has been witnessed that trend and growth of online newspapers are similar alike in the developed and developing world. Most of the newspaper's organization has turned their concentration on digital media hence, the number of online newspapers has increased and all major print and electronic media organization now have online-only media organization in the world. Pakistan is one among developed countries which have embarrassed ICTs in all direction like, major newspapers organizations, and electronic media. For example Dawn English and Jang, the Urdu leading dailies have both online as well as print publications. Also, online pages of dailies are more viewed, surfed and consumed than conventional media. Due to the internet, its reach is beyond borders. All can equally access an online version of newspapers anywhere any time so it has attracted quite a big number of consumers. Consequently, it showed that people are consuming media online now. Based on collected data on newspaper declination and reduced circulation and consumption this study has concluded that print newspapers are falling rapidly and disappeared in developed countries and online newspapers are rising in the world. According to Benton (2018), youth and old are consuming news and information online 
and shifted their interest from conventional format due to immediacy, ease of use and convenience of news.

\section{References}

Ali, O. A. (2009). FM Radio Broadcasting in Pakistan. Report by Pakistan Press Foundation. Retrieved from https://library.fes.de/pdffiles/bueros/pakistan/07235.pdf

Ali, O. A., \& Gunaratne, S. A. (2002). Pakistan. In S. A. Gunaratne (Ed.), Hand Book of the Media in Asia. London: Sage Publication (pp. 155181)

Ariffin, M. Y. M., \& Jaafar, N. I. (2010). Online newspaper in Malaysia: A preliminary study. Jurnal Pengajian Media Malaysia, 11(1).

Benton (2018). What will happen when newspapers kill print and go onlineonly? Most of that print audience will just...disappear. Nieman Journalism. Nieman Foundation at Harvard. Retrieved from https://www.niemanlab.org/2018/09/what-will-happen-whennewspapers-kill-print-and-go-online-only-most-of-that-printaudience-will-just-disappear/?

Boczkowski, P. J. (2005). Digitizing the news: Innovation in online newspapers. MIT Press. Retrieved from https://mitpress.mit.edu/books/digitizing-news

Charney, T., \& Greenberg, B. S. (2002). Uses and Gratifications of the Internet. In C. A. Lin \& D. J. Atkin (Eds.), Communication Technology and Society: Audience Adoption and Uses (pp. 379-408). Cresskill, NJ: Hampton Press.

CIA Fact book (2015) accessed on 1-11-2015, from https://www.cia.gov/library/publications/the-worldfactbook/geos/pk.html.

Eid, M. \& Buchanan, C. (2005). "North America: Multiplying media in a dynamic landscape." First Monday, 10(11). Retrieved 15 April, 2014 from http://www.firstmonday.org/issues/issue10_11/eid/.

Haque, J. (2014). Converging towards Integration. Dawn Aurora. Retrieved from http://aurora.dawn.com/news/1140688 on 05-6-2015

Hermansson, G. (2013). One dollar news: User needs and willingness to pay for digital news content [Doctoral dissertation, RMIT University].

Internet Service Providers Association of Pakistan (ISKAP), "Internet Facts," 26 April 2012. Retrieved from http://www.ispak.pk on 29 June 2014.

Journalism.org. (2007). The state of the news media 2007: An annual report on American Journalism. Retrieved on August 28. 2015, from, http;//www.stateofthejournalismmedia.com/2007/.

Madden, M. (2010). Findings: Older Adults and Social Media. Pew Research Centre. $\quad$ Retrieved from https://www.pewresearch.org/internet/2010/08/27/older-adults-andsocial-media/. 
Media Ownership Monitoring Pakistan (2018). Media Market: Money and Control by Gallup Pakistan was retrieved from https://www.pinterest.com/pin/58265388902832139/

Memon, B., \& Pahore, M. R. (2014). Online Newspaper Exposure by Academics in the Faculty of Social Sciences, University of Sindh, Jamshoro. International Journal of Asian Social Science, 4(1), 70-80

Memon, B., \& Pahore, M. R. (2015). Internet and Online Newspaper Accessing Behaviour of Pakistani Academics: A Survey at Sindh University, Jamshoro. Jurnal Pengajian Media Malaysia, 16(2).

Memon, B. A. (2011). The Role and Status of Journalists in Sindh Province, Pakistan [Doctoral dissertation, University of Leicester].

Memon, B. (2014). Traditional Media Use of Journalists and Audiences in Sindh Province, Pakistan. Review of Journalism and Mass Communication. 2(2), 77-86

Memon, S., \& Shaikh, M. A. (2019). A Conceptual Framework to Measure the Freedom of Press and media Regulation in Pakistan. Journal of Social Sciences \& Humanities 27(2).

Nguyen, A. D. (2007). The diffusion and social impact of online news: Studying the past and present to understand the future of the Internet as a news medium. Australian Journalism Review, 28(1), 143-156.

Nguyen, A. (2008). The Penetration of Online News: past, present and future. The Queensland University. VDM Verlag Dr. Muller Aktienge sells chaft \& Co. KG.

Nguyen, A., Ferrier, L., Western, M. \& McKay, S. (2005). "Online news in Australia: patterns of use and gratification." Australian Studies in Journalism. 15, 5-34.

Okonofua, A. G. (2012). Readership of Online Newspapers by Users of Select Cyber Cafés in Uyo Urban. Paper presented at the Pre-Conference of International Federation of Library Association, Mikkeli, Finland.

Organization for Economic Co-Operation and Development (2009). The Evolution of News and the Internet. Paris: OECD. Report by Directorate for Science, Technology and Industry Committee For Information, Computer And Communications Policy. Retrieved from http://www.oecd.org/digital/ieconomy/45559596.pdf

Pakistan Bureau of Statistics (2006). Pakistan Population. Retrieved from http://www.pbs.gov.pk/sites/default/files/other/pocket_book2006/2.pd $\mathrm{f}$

Pakistan Bureau of Statics report (2012). Pakistan Population. Retrieved from http://www.pbs.gov.pk/content/newspapers-and-periodicals-languageand-province

Pahore, M. R., Memon. S., \& Shahzad. M (2018). Online News Consumption among youth in Malaysia and Pakistan through the lenses of Uses and Gratification Theory. Asia-Pacific 36. 186-199

Popalzai, S. \& Haque, J. (2013, August 20). Pakistan Internet Use Survey 2013. Express Tribune. Retrieved on 22-10-2015, from 
http://tribune.com.pk/story/591004/pakistan-internet-use-survey2013/

PTA Annual report (2016). Retrieved from http://www.pta.gov.pk/en/annualreports on 15 Dec, 2017.

Ricchiardi, S. (2012). Challenges for independent news media in Pakistan. Washington, DC: Center for International Media Assistance.

Rozee Pak poll (2013): retrieved on 20-9-2015, from http://research.rozee.pk/page/2/.

Shokat, A. (2011). Dawn newspaper internship report. Retrieved from https://www.academia.edu/1830531/Dawn_internship_report

Shedden, D. (2010). New Media Timeline (1980). Poynter Online.

World Association of Newspapers (2006). World press trends: newspaper circulation, advertising increases. Press Release, 5 June. Retrieved on 6 June, 2006 from http://www.wan-press.org/article11185.html.

Yoo, C. Y. (2011). Modeling Audience Interactivity as the GratificationSeeking Process in ArrifinOnline Newspapers. Communication Theory, 21(1), 67-89, doi:10.1111/j.1468-2885.2010.01376.x.

Yusuf, H., Dragomir, M., Thompson, M., Watts, G., Chan, Y. Y., Nissen, C. S. \& Tambini, D. (2013). Mapping Digital Media: Pakistan. Open Society Foundations. Retrieved from http://www.pbs.gov.pk/sites/default/files/other/pocket_book2006/2.pd f on 6.12 .2015 